\title{
POLA CORPORATE SOCIAL RESPONBILITY (CSR) DALAM PEMBERDAYAAN USAHA KECIL KERAJINAN ECENG GONDOK DI KECAMATAN BANYUBIRU
}

\author{
Drs. Witjaksono EH, MM \\ Manajemen, Fakultas Ekonomi, Universitas Semarang \\ Diana Puspitasari, SE, MM \\ Akuntansi, Fakultas Ekonomi, Universitas Semarang \\ dianapuspitasari887@yahoo.com
}

\begin{abstract}
The high awareness of the importance of practicing Corporate Social Responsibility (CSR) has become a global trend and lifestyle company with the increasingly widespread concern in the interests of stakeholders. With the sophistication of information technology and market openness without limits brought against company policy to be more serious in considering Corporate Social Responsibility (CSR).

Water hyacinth handicraft industry is one business that is quite well known in the district Banyubiru, Semarang District and is one of the featured products at Semarang district that can contribute to economic growth in the district of Semarang. Water hyacinth handicraft industry in the District Banyubiru, Semarang regency should be developed through Corporate Social Responsibility (CSR).

Corporate Social Responsibility (CSR) will be highly beneficial for SMEs if the water hyacinth program implemented on target and in line with expectations and desires required by craftsmen. So we need good communication between the giver and the recipient of its Corporate Social Responsibility (CSR).
\end{abstract}

Key Word : Corporate Social Responsibility(CSR), Water hyacinth handicraft industry

\begin{abstract}
ABSTRAKSI
Tingginya kesadaran tentang pentingnya mempraktekkan Corporate Social Responbility (CSR) sudah menjadi trend global dan gaya hidup perusahaan dengan semakin maraknya kepedulian dalam mengutamakan kepentingan stakeholder. Dengan adanya kecanggihan teknologi informasi dan keterbukaan pasar tanpa batas membawa kebijakan terhadap perusahaan agar lebih serius lagi dalam memperhatikan Corporate Social Responbility (CSR).

Industri kerajinan enceng gondok merupakan salah satu usaha yang cukup terkenal di Kecamatan Banyubiru, Kabupaten Semarang dan merupakan salah satu produk unggulan di Kabupaten Semarang yang dapat memberikan sumbangan bagi pertumbuhan ekonomi di Kabupaten Semarang. Industri kerajinan enceng gondok di Kecamatan Banyubiru, Kabupaten Semarang perlu dikembangkan melalui program Corporate Social Responbility(CSR).

Corporate Social Responbility (CSR) akan sangat bermanfaat untuk UKM eceng gondok apabila program yang dilaksanakan tepat sasaran dan sesuai dengan harapan serta keinginan yang dibutuhkan oleh pengrajin. Maka dibutuhkan komunikasi yang baik antara pemberi dan penerima program Corporate Social Responbility (CSR).
\end{abstract}

Kata Kunci : Corporate Social Responbility (CSR, Industri kerajinan enceng gondok 


\section{PENDAHULUAN}

Dalam era persaingan usaha yang semakin beragam dan ketatnya persaingan antar usaha memaksa para pelaku usaha industri maupun perusahaan untuk semakin inovatif dan kreatif dalam menciptakan sebuah produk yang tidak hanya bernilai secara ekonomis tetapi mampu merespon masalah dan bentuk tanggung jawab terhadap lingkungan sosial dan lingkungan berupa implementasi Corporate Social responbility (CSR). Bentuk tanggung jawab sosial dari perusahaan akibat aktivitas yang dilakukan perusahaan yang bersangkutan tercermin dalam kompensasi kepedulian dengan masyarakat di sekitar operasional lingkungan perusahaan. Di Kabupaten Semarang tepatnya di Kecamatan Banyubiru, terdapat sektor industri kreatif yang memiliki potensi besar untuk dimanfaatkan, yaitu industri kerajinan eceng gondok. Permasalahan yang mendasar dalam UKM kerajinan eceng gondok di Kecamatan Banyubiru, adalah ternyata program Corporate Social Responbility (CSR) yang selama ini berjalan belum sesuai dengan harapan dan keinginan dari para pengrajin eceng gondok itu sendiri.

Menurut Sukarno (2008), tanggung jawab sosial (Corporate Social Responbility atau CSR) kurang diperhatikan para pelaku industri, cenderung hanya sebatas diperhatikan tetapi tidak dilakukan dengan baik. Sehingga dampaknya adalah masih minimnya program-program pembinaan, pemberdayaan, kemitraan, dan pengembangan organisasi. Dampak dari program Corporate Social Responbility (CSR) bisa dirasakan mulai dari pengurangan pengangguran dengan merangkul warga sekitar sebagai pengrajin dan melatihnya sehingga mempunyai keterampilan yang memadai hingga mampu menciptakan kemandirian, yaitu mampu menghidupi dirinya sendiri dan orang lain dari hasil kerajinan eceng gondok, sampai mampu memberikan kontribusi berupa pemasukan pendapatan bagi pemerintah setempat. Tetapi kurangnya komunikasi yang baik antara pengrajin dengan pihak pemberi Corporate Social Responbility (CSR) menjadi kendala dalam suksesnya program Corporate Social Responbility $(C S R)$ yang diterima oleh pengrajin.

\section{RUMUSAN MASALAH}

Berdasarkan latar belakang permasalahan yang telah diuraikan di atas, maka dapat dirumuskan permasalahan penelitian sebagai berikut : Bagaimana implementasi program CSR (Corporate Social Responbility atau CSR) pada UKM kerajinan eceng gondok di Kecamatan Banyubiru, Kabupaten Semarang?

\section{Tujuan Penelitian}

Sesuai dengan permasalahan dan pertanyaan penelitian di atas maka tujuan yang hendak dicapai dalam penelitian ini dapat dirinci sebagai berikut : Untuk mengetahui implementasi penerapan CSR (Corporate Social Responbility atau CSR) yang tepat dalam pemberdayaan UKM kerajinan eceng gondok di Kecamatan Banyubiru, Kabupaten Semarang. 


\section{Manfaat Penelitian}

Manfaat hasil penelitian yang akan disampaikan adalah sebagai berikut :

1. Bagi Pengrajin eceng gondok : diharapkan dapat memberikan gambaran tentang implementasi CSR (Corporate Social Responbilityatau CSR) yang telah berjalan.

2. Bagi Instansi terkait : diharapkan dapat memberikan kontribusi terhadap penerapan tanggung jawab sosial atau CSR (Corporate Social Responbility atau CSR ) secara efektif bagi instansi-instansi di Indonesia.

3. Bagi para peneliti : diharapkan dapat dijadikan sebagai masukan bagi penelitian lebih lanjut dengan topik yang sama.

\section{KAJIAN PUSTAKA}

\section{Corporate Social Responbility (CSR)}

Corporate Social Responbility atau CSR merupakan tanggung jawab bagi suatu organisasi (khususnya, tapi tidak terbatas pada, perusahaan) dengan kewajiban untuk memperhatikan kepentingan pelanggan, karyawan, pemegang saham, komunitas dan pertimbangan-pertimbangan ekologis dalam segala aspek dari usahanya (Ashogu, 2009). Tanggung jawab sosial perusahaan (Corporate Social Responsibility) saat ini bukan lagi sebagai slogan popularitas bagi perusahaan, akan tetapi sudah merupakan Kebijakan dari Pemerintah terutama bagi Badan Usaha Milik Negara dan Daerah (BUMN dan BUMD) untuk menyisihkan dana sebesar 5-10\% untuk dialokasikan sebagai aktivitas kepedulian terhadap lingkungan perusahaan dan sosial sebagai bentuk kinerja sosial perusahaan atau Corporate Social Performance (Sukarno, 2008).

\section{Konsep UKM}

Usaha Mikro Kecil dan Menengah (UMKM) menurut Sumodiningrat (2007) dalam Sukarno (2008), mempunyai ciri utama: (1) pada umumnya dalam berusaha tidak memisahkan kedudukan pemilik dengan manajerial; (2) menggunakan tenaga kerja sendiri; (3) unbankable mengandalkan modal sendiri, (4) sebagian tidak berbadan hukum dan memiliki tingkat kewirausahaan yang relatif rendah. Kriteria lain menurut Bank Indonesia adalah: (1) kepemilikan oleh individu atau keluarga;(2) memanfaatkan teknologi sederhana dan padat karya; (3) rata-rata tingkat pendidikan dan keterampilan tergolong rendah; (4) sebagian tidak terdaftar secara resmi dan atau belum berbadan hukum serta; (5) tidak membayar pajak. Ada dua definisi usaha kecil yang dikenal di Indonesia. Pertama, definisi usaha kecil menurut Undang-Undang No. 9 tahun 1995 tentang Usaha Kecil adalah kegiatan ekonomi rakyat yang memiliki hasil penjualan tahunan maksimal Rp 1 milyar dan memiliki kekayaan bersih, tidak termasuk tanah dan bangunantempat usaha, paling banyak $\mathrm{Rp} 200$ juta. Kedua, menurut kategori Badan PusatStatistik (BPS), usaha kecil identik dengan industri kecil dan industri rumah tangga. BPS mengklasifikasikan industri berdasarkan jumlah pekerjanya, yaitu:(1) industri rumah tangga dengan pekerja 1-4 orang; (2) industri kecil dengan pekerja 5-19 orang; (3) industri menengah dengan pekerja 20-99 orang; dan (4) industri besar dengan pekerja 100 orang atau lebih. 


\section{Pemberdayaan UKM}

Memberdayakan mengandung pula arti melindungi. Dalam proses pemberdayaan, harus dicegah yang lemah menjadi bertambah lemah, dalam menghadapi yang kuat. Pemberdayaan masyarakat lokal dan jaminan hak-hak masyarakat disekitar daerah operasional perusahaan merupakan kewajiban yang harus dilaksanakan. Pemberdayaan masyarakat yang efektif membuat masyarakat menjadi berdaya guna dan adaptif terhadap perubahan yang terjadi di lingkungannya. Menurut Syarif (2001) dalam Sukarno (2008), yang dimaksud dengan pemberdayaan adalah merupakan suatu upaya untuk membangun daya (masyarakat) dengan mendorong, memotivasi dan membangkitkan kesadaran akan potensi yang dimilikinya serta berupaya untuk mengembangkannya. Keberdayaan masyarakat adalah unsur dasar yang memungkinkan suatu masyarakat bertahan dan mengembangkan diri untuk mencapai kemajuan.

\section{METODE PENELITIAN}

\section{Jenis Penelitian}

Penelitian ini menggunakan penelitian deskriptif eksploratif, dimana dilakukan analisis data hanya sampai taraf deskripsi saja yaitu menganalisis dan menyajikan data secara sistematik sehingga mudah untuk dipahami. Menurut Arikunto (2002), penelitian deskriptif eksploratif bertujuan untuk menggambarkan keadaan suatu fenomena, dimana dalam penelitian ini tidak menggunakan hipotesa tetapi hanya menjelaskan gambaran adanya suatu variabel, gejala atau keadaan. Proses pelaksanaan penelitian deskriptif eksploratif berusaha menggali secara luas penyebab terjadinya fenomena dan kondisi permasalahan yang terjadi pada saat itu. Keadaan yang digambarkan dalam penelitian ini adalah bagaimana pelaksanaan program Corporate Social Responbility (CSR) yang diterapkan untuk para pengrajin eceng gondok di kecamatan Banyubiru apakah sudah terealisasi secara baik dan tepat sasaran, atau justru sebaliknya.

\section{Subjek Penelitian}

Subjek penelitian yang digunakan sebagai sampel dalam penelitian ini adalah pengrajin eceng gondok di kecamatan Banyubiru yang tergabung dalam Klaster Eceng Gondok bernama Klaster Klinting yang terdiri dari 7 (tujuh) pengrajin.

\section{Jenis dan Sumber Data}

Jenis data dalam penelitian ini adalah data primer dan data sekunder. Data primer diperoleh langsung dari informan yaitu pengrajin eceng gondok, sedangkan data sekunder dalam penelitian ini adalah data persebaran UKM di Kecamatan Banyubiru, yang diperoleh dari Dinas Perindustrian, Perdagangan, dan Koperasi Kabupaten Semarang. 


\section{Teknik Pengumpulan Data}

Teknik pengumpulan data yang digunakan dalam penelitian ini adalah interview atau wawancara dengan pengrajin eceng gondok yang tergabung dalam Klaster Klinting, melakukan observasi, dan dokumentasi kegiatan dan pelaksanaan penelitian.

\section{Teknik Analisis Data}

Analisis data yaitu proses mengorganisasikan dan mengurutkan data ke dalam pola, kategori dan uraian dasar sehingga dapat ditemukan tema dapat disimpulkan, bahwa analisis data adalah suatu langkah untuk menyederhanakan hasil penelitian dengan menggunakan analisa yang tajam dan sistematis dengan maksud agar penelitian yang dihasilkan dapat mudah dipahami secara mendalam dan menyeluruh. Di dalam pelaksanaan penelitian ini, setelah data terkumpul maka data tersebut di analisis dengan cara eksploratif. Eksploratif adalah menggali secara luas tentang sebab-sebab atau hal-hal yang mempengaruhi terjadinya sesuatu.

\section{PEMBAHASAN}

\section{Profil Industri Kecil Kerajinan Eceng Gondok di Kecamatan Banyubiru}

Industri kerajinan enceng gondok merupakan salah satu usaha yang cukup berkembang di Kecamatan Banyubiru, Kabupaten Semarang. Industri ini mulai dikembangkan ketika produk industri kerajinan dan meubel dengan bahan baku dari kayu semakin menurun jumlahnya. Industri yang memanfaatkan bahan baku dari tanaman enceng gondok ini memiliki daya saing yang tinggi dan mampu menyerap teniga kerja. Unit usaha industri kecil kerajinan enceng gondok di Kecamatan Banyubiru tersebar di beberapa desa yaitu desa Banyubiru, desa Kebondowo, desa Tegaron, dan desa Rowoboni.

\section{Pelaksanaan Corporate Social Responbility (CSR) di Kecamatan Banyubiru}

Pelaksanaan program Corporate Social Responbility (CSR) di kecamatan Banyubiru sekiranya dapat membantu industri kerajinan eceng gondok untuk berkembang dan maju. Beberapa program Corporate Social Responbility (CSR) di kecamatan Banyubiru yang diterima oleh pengrajin eceng gondok belum sepenuhnya berjalan dengan baik, dikarenakan ada beberapa program yang tidak sesuai dengan harapan pengrajin, salah satunya adalah program bantuan peralatan yang tidak sesuai. 


\section{KESIMPULAN，KETERBATASAN DAN SARAN}

\section{Kesimpulan}

Dari hasil penelitian yang diperoleh di lapangan dapat disimpulkan bahwa :

1. Penerapan program CSR (Corporate Social Responbility) yang dilakukan oleh dinas terkait dan perusahaan lainnya sebetulnya sudah berjalan dengan baik. Dengan seringnya memberikan penyuluhan dan pelatihan sebagai bekal kemandirian dapat mendorong peningkatan dalam berkarya karena mereka menjadi lebih berani dan yakin dalam usahanya.

2. Penerapan program Corporate Social Responbility (CSR) sangat bermanfaat dan dapat membantu UKM eceng gondok gondok untuk berkembang dalam permodalan dan pemasaran produk, juga dirasakan dapat mengatasi jumlah pengangguran yang ada di Kecamatan Banyubiru, tetapi masih ada beberapa program CSR dari beberapa perusahaan yang dirasa tidak sesuai dengan kebutuhan pengrajin.

3. Pemberdayaan UKM sudah terlihat dengan adanya kemitraan antar pengrajin. Dimana pengrajin yang sudah cukup besar dan sudah maju saling bekerjasama, merangkul pengrajin yang masih berskala kecil, misalkan dalam hal pembagian order pesanan, dan pengrajin yang sudah besar ikut memberikan pelatihan bagi pengrajin yang masih berskala kecil.

4. Ketidaktahuan UKM terhadap cara memperoleh pinjaman terkait syarat dan nominal agunan seringkali menjadi kendala dan dirasakan oleh pemilik usaha. Tetapi dengan adanya program CSR (Corporate Social Responbility) yang dilakukan oleh dinas terkait dan lembaga keuangan dan non keuangan lainnya mampu menjembatani kebutuhan pengrajin eceng gondok dan memberikan kemudahan bagi mereka untuk terus berkembang.

5. Beberapa program CSR (Corporate Social Responbility) dalam pemberian beberapa bantuan mesin dan peralatan belum sesuai dengan keinginan dan harapan para pengrajin eceng gondok.

\section{Keterbatasan Penelitian}

Penelitian ini memiliki keterbatasan terutama dalam hal subjek penelitian, yaitu sebagai berikut :

1. Subjek penelitian masih terbatas pada pengrajin eceng gondok yang tergabung dalam satu klaster, sehingga diperoleh informan dan informasi yang masih terbatas.

2. Informasi yang digali hanya terbatas pada pengrajin eceng gondok sebagai penerima program Corporate Social Responbility $(C S R)$.

\section{Agenda Penelitian Mendatang}

1. Terkait dengan subjek penelitian, diharapkan memilih sasaran yang lebih luas lagi tidak hanya mencakup pengrajin eceng gondok yang tergabung dalam klaster saja.

2. Melakukan wawancara lebih mendalam lagi kepada kedua belah pihak, yang pertama instansi sebagai pemberi program Corporate Social Responbility (CSR), dan yang 
kedua adalah pengrajin eceng gondok sebagai penerima Corporate Social Responbility (CSR) agar mendapatkan data dan informasi yang lebih akurat.

\section{Saran}

Saran yang dapat disampaikan adalah sebagai berikut :

1. Industri kerajinan enceng gondok di Kecamatan Banyubiru, Kabupaten Semarang perlu dikembangkan serta ditingkatkan, mengingat kerajinan enceng gondok merupakan salah satu produk unggulan di Kabupaten Semarang yang dapat memberikan sumbangan bagi pertumbuhan ekonomi di Kabupaten Semarang. Dengan bantuan permodalan melalui program Corporate Social Responbility (CSR) dapat mendorong daya usaha pengrajin dalam mempertahankan eksitensi usahanya.

2. Program Corporate Social Responbility (CSR) dapat berjalan dengan baik apabila sesuai dengan kebutuhan pengrajin, sehingga dibutuhkan komunikasi yang baik untuk mengetahui keinginan dan harapan para pengrajin eceng gondok, khususnya dalam hal pemberian bantuan mesin dan peralatan agar bisa digunakan dan sesuai dengan standar atau spesifikasi usaha yang dibutuhkan.

3. Corporate Social Responbility (CSR) akan sangat bermanfaat untuk UKM eceng gondok apabila program yang dilaksanakan tepat sasaran dan sesuai dengan harapan serta keinginan yang dibutuhkan oleh pengrajin. Maka dibutuhkan komunikasi yang baik antara pemberi dan penerima program Corporate Social Responbility $(C S R)$.

\section{DAFTAR PUSTAKA}

Sukarni. "Tanggug Jawab Sosial Perusahaan (CSR) dan Iklim Penanaman Modal", http://www.djpp.depkumham.go.id/, diunduh pada 5 Juni 2012,

Sutarto "Good Corporate Governance (GCG): Corporate Social Responsibility (CSR) dan Pemberdayaan UMKM", http://www.diskopjatim.go.id/

Sukarno, gendut, 2006, Kontribusi Pemberdayaan Usaha Kecil Dalam Meningkatkan Kinerja Industri Sepatu dan Sandal di Kabupaten Sidoarjo, Prociding dalam Seminar Nasional "Pemberdayaan Usaha Kecil dalam Perspektif Global"

Sukarno, Gendut, 2008, Kontribusi Corporate Social Responbility Terhadap Corporate Social Performance Pada Beberapa Industri di Sidoarjo, Prociding dalam Seminar Nasional Teknologi VI "Perandan Strategi Manajemen Teknologi Guna Meningkatkan Sustainabilitas Industri dan Bisnis dalam Menghadapi Era Globalisasi"

Sulistyaningtyas, I. D. (2006). Tanggung Jawab Sosial Perusahaan dalam Program Kampanye Sosial. Jurnal Ilmu Komunikasi, Vol. 3 No. 1, 63-76

T. Romi Marnelly, 2012, CORPORATE SOCIAL RESPONSIBILITY (CSR) : Tinjauan Teori dan Praktek di Indonesia, Jurnal Aplikasi Bisnis Vol. 2 No. 2, April 2012.

Widjaja, G., \& Yeremia, A. P. (2008). Risiko Hukum dan Bisnis Perusahaan Tanpa CSR. Jakarta: Forum Sahabat. 